\title{
The cell walls of green algae: a journey through evolution and diversity
}

\section{David S. Domozych ${ }^{1}$, Marina Ciancia ${ }^{2}$, Jonatan U. Fangel ${ }^{3}$, Maria Dalgaard Mikkelsen $^{3}$, Peter Ulvskov $^{3}$ and William G. T. Willats ${ }^{3}$}

${ }_{1}^{1}$ Department of Biology and Skidmore Microscopy Imaging Center, Skidmore College, Saratoga Springs, NY, USA

${ }^{2}$ Cátedra de Química de Biomoléculas, Departamento de Biología Aplicada y Alimentos, Facultad de Agronomía, Universidad de Buenos Aires, Buenos Aires, Argentina

${ }^{3}$ Department of Plant Biology and Biochemistry, Faculty of Life Sciences, University of Copenhagen, Frederiksberg, Denmark

\section{Edited by:}

Jose Manuel Estevez, University of Buenos Aires and Consejo Nacional de Investigaciones Científicas y Técnicas, Argentina

Reviewed by:

Malcolm ONeill, University of Georgia, USA

Zoë A. Popper, National University of Ireland, Ireland

\section{${ }^{*}$ Correspondence:}

David S. Domozych, Department of Biology and Skidmore Microscopy Imaging Center, Skidmore College 815 North Broadway, Saratoga Springs, NY 12866, USA.

e-mail:ddomoz@skidmore.edu
The green algae represent a large group of morphologically diverse photosynthetic eukaryotes that occupy virtually every photic habitat on the planet. The extracellular coverings of green algae including cell walls are also diverse. A recent surge of research in green algal cell walls fueled by new emerging technologies has revealed new and critical insight concerning these coverings. For example, the late divergent taxa of the Charophycean green algae possess cell walls containing assemblages of polymers with notable similarity to the cellulose, pectins, hemicelluloses, arabinogalactan proteins (AGPs), extensin, and lignin present in embryophyte walls. Ulvophycean seaweeds have cell wall components whose most abundant fibrillar constituents may change from cellulose to $\beta$-mannans to $\beta$-xylans and during different life cycle phases. Likewise, these algae produce complex sulfated polysaccharides, AGPs, and extensin. Chlorophycean green algae produce a wide array of walls ranging from cellulose-pectin complexes to ones made of hydroxyproline-rich glycoproteins. Larger and more detailed surveys of the green algal taxa including incorporation of emerging genomic and transcriptomic data are required in order to more fully resolve evolutionary trends within the green algae and in relationship with higher plants as well as potential applications of wall components in the food and pharmaceutical industries.

Keywords: cell walls, scales, green algae, sulfated polysaccharides, glycoproteins

\section{INTRODUCTION}

The emergence of green algae (Chlorophyta and Streptophyta, Viridiplantae; sensu Leliaert et al., 2012) onto land roughly 470 million years ago represents one of the most important events in the history of life on the planet. Their successful colonization of land and subsequent evolution into modern land plants significantly altered the atmosphere, changed terrestrial substrates and paved the way for the evolution of other biota. Today, humans ultimately depend on the evolutionary "offshoots" of green algae (i.e., embryophytes or "land plants") for food, textiles, building material, pharmaceuticals, and fuels. Yet these events and applications represent only parts of a much larger story of green algae. Contemporary green algae are ubiquitous. They are important members of the ocean's phytoplankton, common and sometimes nuisance seaweeds of coastal marine habitats, peculiar symbionts of lichens and flatworms, and inhabitants of just about any freshwater ecosystem ranging from ponds, rivers, lakes, wetlands, and snow banks. In the 1.5 billion years since they first appeared (Lewis and McCourt, 2004; Becker and Marin, 2009; Finet et al., 2010; Leliaert et al., 2011; Wodnick et al., 2011), green algae have successfully adapted to virtually all photic zones of the planet.

Similar to their land plant offspring, the vast majority of extant green algae today are covered by a very large assortment of types of extracellular matrix (ECM). These external coverings are products of complex biosynthetic machineries that often make use of the bulk of the alga's photosynthetically fixed carbon. The ECM is integral to growth and development, affords the alga physical protection and defense against microbial attack, is involved in cell-cell and cell-substrate adhesion and in some cases, is involved in sexual reproduction. Some green algae are covered by multiple layers of intricately sculpted scales while others have crystalline glycoprotein coverings or thick multilaminate fibrillar cell walls. A few taxa though have cell walls with remarkable structural and biochemical similarity to cell walls found in land plants (Sørensen et al., 2010, 2011). How did these diverse extracellular coverings arise and what are the evolutionary links between them? Many analytical approaches and technologies are now being used to study green algal ECMs and are providing new and critical insight into structure, chemistry, and evolution of these coverings (Table 1). Nevertheless, we are only in an infancy stage in our understanding of the green algal extracellular coverings. In this review, we describe some of these recent discoveries and comment on future directions for study of the cell walls of green algae.

\section{THE CURRENT STATE OF STUDY OF GREEN ALGAL CELL WALLS AND EXTRACELLULAR COVERINGS}

While the green algae display a large and diverse array of ECMcoverings, only a few taxa have been studied in detail. It is widely accepted that taxa of the Ulvophyceae and the Charophycean green algae (CGA) possess fibrillar cell walls (Popper et al., 2011) consisting of various polysaccharide and proteoglycan constituents while other taxa, especially those of the Prasinophyceae, 
Table 1 | Major methodologies used today in the study of green algal coverings.

\begin{tabular}{|c|c|c|c|}
\hline Methodology & Technical aspects & Data obtained/status & Reference \\
\hline Biochemical & $\begin{array}{l}\text { Chemical and enzymatic fractionation; } \\
\text { methylation analysis-GC/MS; NMR; } \\
\text { electrophoresis }\end{array}$ & $\begin{array}{l}\text { Monosaccharide composition, glycosidic linkage } \\
\text { composition, conformational studies, molecular weights } \\
\text { of various cell wall polysaccharides }\end{array}$ & $\begin{array}{l}\text { Popper et al. (2011), } \\
\text { Popper and Fry (2003), } \\
\text { Estevez et al. (2009) }\end{array}$ \\
\hline $\begin{array}{l}\text { Carbohydrate } \\
\text { microarrays }\end{array}$ & $\begin{array}{l}\text { Sequential extraction of } \\
\text { polysaccharides; immobilization onto } \\
\text { nitrocellulose, mAb probing }\end{array}$ & $\begin{array}{l}\text { Early divergent CGA walls differ from late divergent taxa } \\
\text { walls; late divergent taxa possess HGA, RG-I, MLG, } \\
\text { various hemicelluloses, AGPs, extensins }\end{array}$ & $\begin{array}{l}\text { Sørensen et al. (2010, } \\
\text { 2011), Moller et al. } \\
\text { (2007) }\end{array}$ \\
\hline $\begin{array}{l}\text { FTIR } \\
\text { microspectroscopy }\end{array}$ & $\begin{array}{l}\text { IR spectral arrays obtained from } \\
\text { microscopically imaged covering }\end{array}$ & $\begin{array}{l}\text { Analysis of presence and distribution of polymers in the } \\
\text { cell wall of Ulvophyceae }\end{array}$ & $\begin{array}{l}\text { Estevez et al. (2009), } \\
\text { Fernández et al. (2011a), } \\
\text { Carpita et al. (2001) }\end{array}$ \\
\hline
\end{tabular}

mAb, monoclonal antibody; RG-I, rhamnogalacturonan-I; $M L G$, mixed linkage glucans; AGP, arabinogalactan protein; FTIR, Fourier transform infrared; CGA, Charophycean green algae.

Chlorodendrophyceae, and some taxa of the Chlorophyceae, produce coverings that are structurally and biochemically unique. Presently, extant green algae are classified into six distinct clades (Delwiche and Timme, 2011; Leliaert et al., 2011, 2012). The following represent brief synopses of the current state of knowledge concerning the ECM of these groups (see also Table 2).

\section{THE PRASINOPHYCEAEN MATRIX: SUBTLE TO THE SPECTACULAR!}

The Prasinophyceae or prasinophytes represent a group of motile and non-motile unicells that are presently classified in four clades (Leliaert et al., 2012) and are most commonly found in marine habitats. In photic zones of oceans, picoplanktonic prasinophytes (perhaps the smallest extant eukaryotes; $0.8 \mu \mathrm{m}$ cell size), like Ostreococcus and Micromonas, exist in very large numbers. Previous microscopy-based research has shown that taxa like these are either covered with scales or do not have any discernable matrix at all (i.e., they are naked; Piganeau et al., 2011). However, recent analysis of the Ostreococcus genome plus immunocytochemical investigations in our laboratories together raise questions as to the nakedness of this picoalga. Other prasinophytes are significantly larger and covered with layers of thousands of distinctly shaped scales coating both the cell and flagellar membrane surfaces (Moestrup and Walne, 1979). Biochemical analyses have shown that these scales are comprised primarily of neutral and acidic sugars including 2-keto sugars such as 3-deoxy-lyxo-2-heptulosaric acid (DHA; Becker et al., 1991, 1994). All scales of prasinophytes are believed to be processed in the Golgi apparatus, packaged in secretory vesicles and secreted to the cell surface near the flagellar apparatus or to vacuole-like scale reservoirs before release to the cell surface.

\section{CHLORODENDROPHYCEAE: WALLS FROM A FUSION}

Taxa of the small Chlorodendrophyceae group of green algae consist of motile or non-motile and sometimes stalked unicells (Tetraselmis and Scherffelia) that are covered by a single cell wall or layers of cell walls. Furthermore, the wall or theca consists of regular repeating subunits and unlike the cell walls of other green algae, this wall is believed to be a product of fused scales. The subunits of the theca are scale-like and are processed in the Golgi apparatus like those of scaly prasinophytes. The acid sugars, 2-keto-3-deoxy-D-manno-octulosonic acid, 5-O-methyl 2-keto3 -deoxy-D-manno-octulosonic acid, and DHA comprise $60 \%$ of the sugars present in the theca (Becker et al., 1991).

\section{TREBOUXIOPHYCEAE: WALLS OF UNUSUAL POLYMERS}

The Trebouxiophyceae consists of an assemblage of primarily freshwater and terrestrial forms that exhibit diverse phenotypes ranging from unicells to colonies to filaments as well as representing most of the photobiont green algae of lichens (e.g., Trebouxia). Some are considered highly attractive candidate genera for use in algal biofuel production (e.g., Chlorella; Rodrigues and da Silva Bon, 2011). Most members of this group possess cell walls but surprisingly little is known about their biosynthesis, composition, or architecture. In Chlorella, the wall contains cellulose and in some species, the wall is coated by a highly resistant outer stratum consisting of "algaenan," an aliphatic polymer containing long polymethylenic chains that are decorated with amide and $N$-alkyl substituted pyrroles (Rodrigues and da Silva Bon, 2011). In Trebouxia isolated from lichens and grown separately from its fungal partner, $\beta$-galactofuranan has been demonstrated, a polysaccharide previously found in fungi but not known from green algae (Cordeiro et al., 2006). 
Table 2 | Summary of the composition of extracellular coverings in green algae.

\begin{tabular}{|c|c|c|c|}
\hline Taxon & Covering type & Biochemical composition & Reference \\
\hline Prasinophyceae & "Scales," coatings & 2-Keto sugars (e.g., DHA), mannans, glycoproteins & $\begin{array}{l}\text { Becker et al. (1991, 1994), Moestrup } \\
\text { and Walne (1979) }\end{array}$ \\
\hline Trebouxiophyceae & Cell walls & Cellulose, algaenan, $\beta$-galactofuranan & $\begin{array}{l}\text { Rodrigues and da Silva Bon (2011), } \\
\text { Cordeiro et al. (2006) }\end{array}$ \\
\hline Ulvophyceae & Cell walls & $\begin{array}{l}\text { Cellulose, } \beta \text {-mannans, } \beta \text {-xylans, sulfated (sometimes } \\
\text { pyruvylated) polysaccharides or sulfated } \\
\text { rhamnogalacturonans, AGP, extensin }\end{array}$ & $\begin{array}{l}\text { Ciancia et al. (2012), Estevez et al. } \\
\text { (2009), Percival (1979), Lahaye and } \\
\text { Robic (2007) }\end{array}$ \\
\hline $\begin{array}{l}\text { Charophyceae-early } \\
\text { divergent clades }\end{array}$ & Scales, cell walls & $\begin{array}{l}\text { 2-Keto sugars, cellulose, homogalacturonans, 1,3 } \\
\beta \text {-glucans, AGP }\end{array}$ & $\begin{array}{l}\text { Sørensen et al. (2011), Domozych et al. } \\
\text { (1991) }\end{array}$ \\
\hline
\end{tabular}

For further detailed information, key references are provided. AGP, arabinogalactan proteins; Hyp, hydroxyproline.

\section{CHLOROPHYCEAE: GLYCOPROTEINS AND CELLULOSE}

The Chlorophyceae are the largest group of green algae and exhibit great morphological diversity ranging from motile unicells to large filaments to blade-like thalli. The extracellular coverings of the Chlorophycean algae are also very diverse and consist of a distinct assortment of "cell walls." In Oedogonium, the cell wall resembles those of higher plants in containing microfibrillar cellulose, homogalacturonans and rhamnogalacturonan-I, extensin, and arabinogalactan constituents (Estevez et al., 2008). Many of the polysaccharides that are common to embryophyte walls are thought to have evolved within the CGA, so these results were unexpected. Further biochemical study and a much wider screening of this and other Chlorophycean taxa will be required to ascertain the similarity of these polymers with those of the CGA and embryophytes. However, in the Chlamydomonas-Volvox assemblage (i.e., volvocalean flagellates), the cell wall does not contain cellulose but is made of crystalline glycoproteins, specifically one based upon aggregates of hydroxyproline-rich glycoproteins (HRGPs) and glycine-rich glycoproteins (Imam et al., 1985; Adair et al., 1987; Kirk, 1998; Voigt et al., 2001, 2007). Extensins of plants are a group of cell wall glycoproteins that probably share at least some glycosylation motives and a common ancestry with the HRGPs of Chlamydomonas-Volvox assemblage. The glycosylation motives that govern extensin-type glycosylation comprise the SPPPP sequence (i.e., serine-proline-proline-proline-proline) usually occurring several times. The prolines are hydroxylated by prolyl hydroxylases prior to glycosylation. Showalter et al. (2010) used SPPPSPPP to define the class of extensins in their bioinformatic classification of HRGPs. The genetic encoding of the repetitive structures allows for substantial genetic drift without loss of function (Kieliszewski and Lamport, 1994), this being the reason why clear orthologies between individual vascular plant and chlorophyte extensins cannot be traced. The core arabinosylation machinery is clearly equivalent, however. Egelund et al. (2007) used the phylogenetic distances between family GT77 glycosyltransferases to deduce the function of the Arabidopsis GT77 clade A genes. This proposition that the genes encode extensin arabinosyltransferases, was later corroborated by extensin phenotypes of mutants knocked out in these genes (Velasquez et al., 2011). The prolyl hydroxylases described in that paper also have orthologs in the chlorophyte genomes and one from Chlamydomonas has been shown to be involved in cell wall biogenesis (Keskiaho et al., 2007) and the CAZy-database classifies Chlamydomonas gene BAF46284 to family GT75. The encoded protein is 68.6\% identical to Arabidopsis At3g02230, one of the mutases that catalyzes the interconversion of UDP-Arap and UDP-Araf (Rautengarten et al., 2011), which we believe to be the donor substrate also of these arabinosyl transferases.

\section{ULVOPHYCEAE: SULFATED POLYSACCHARIDES, FIBRILLAR POLYMERS, AND GLYCOPROTEINS}

The Ulvophyceae area diverse assemblage of organisms including the best known marine seaweeds with siphonocladous, siphonous, and filamentous forms (Leliaert et al., 2012). Some of them have cellulose as a major fibrillar component of their cell walls. However, others possess $(1 \rightarrow 4)-\beta$-mannans or $(1 \rightarrow 3)-\beta$-xylans (Percival and McDowell, 1981; Painter, 1983; Yamagaki et al., 1997; Dunn et al., 2007; Estevez et al., 2009; Ciancia et al., 2012) and in some, the type of fibrillar polysaccharide is life cycle stagedependent (Huizing and Rietema, 1975; Wutz and Zetsche, 1976; Huizing et al., 1979; Dunn et al., 2007).

These algae synthesize sulfated polysaccharides, an adaptation to the marine habitats that is also observed in many other marine organisms, including angiosperms and invertebrates (Aquino et al., 2011). These sulfated wall constituents may be classified into one of two groups as originally designated by Percival (1979): (1) uronic acid-rich polysaccharides also containing rhamnose, xylose, and sometimes galactose, and (2) uronic acid-limited polysaccharides consisting of major quantities of galactose, arabinose and, in some cases, xylose. The first group is represented by Ulva, 
Monostroma, Gayralia, and Acetabularia (Ray, 2006; Chattopadhyay et al., 2007a; Dunn et al., 2007; Lahaye and Robic, 2007; Cassolato et al., 2008; Mao et al., 2008, 2009) and the second one includes Caulerpa, Codium, and Bryopsis (Bilan et al., 2007; Chattopadhyay et al., 2007b; Estevez et al., 2009; Ciancia et al., 2012).

Cell walls from the first group as represented by several Ulva species comprise two major polysaccharide components, soluble ulvans and cellulose, and two minor ones, an alkali-soluble linear xyloglucan and a glucuronan. Ulvan is the family of sulfated polysaccharides that consist of large quantities of glucuronic acid and rhamnose with the main repeating disaccharide being $\rightarrow 4)-\beta$-DGlcA $p$ - $(1 \rightarrow 4)-\alpha$-L-Rhap- $(1 \rightarrow . \alpha$-L-Iduronic acid or $\beta$-xylose can replace glucuronic acid to a certain extent with the latter sugar also found as a side chain linked to C-2 of some rhamnose residues. Sulfation appears mostly on C-3 of the rhamnose units and on C-2 of the glucuronic acid side chains. Distribution of these polymers in the cell walls of the bi-seriated thallus of Ulva was determined by cytochemical and physicochemical data (Lahaye and Robic, 2007). These polymers are structurally related to glycosaminoglycans from animal tissues, like chondroitin sulfate or heparin, but they have glucosamine units instead of rhamnose in their backbone, and the sulfation pattern is different.

The second group is represented by coenocytic Codium species, which produce a 4 -linked $\beta$-D-mannan as fibrillar component. Three different sulfated polysaccharide structures were isolated from $C$. vermilara including: (1) highly ramified sulfated and pyruvylated $\beta$ - $(1 \rightarrow 3)$-D-galactans, also present in other Codium species (Bilan et al., 2007; Ciancia et al., 2007; Farias et al., 2008; Ohta et al., 2009; Fernández et al., 2011a); (2) linear highly sulfated $\beta$ - $(1 \rightarrow 3)-\mathrm{L}$-arabinans, with the arabinose units in the pyranose form (P. V. Fernandez, J. M. Estevez, A. S. Cerezo, and M. Ciancia, unpublished results); and (3) linear $\beta$ - $(1 \rightarrow 4)$-D-mannans partially sulfated mainly on C-2 of some of the mannose units (Fernández et al., 2011b). Also, HRGPs with characteristics similar to those of arabinogalactan proteins (AGPs) and extensins from vascular plants were detected in these cell walls (Estevez et al., 2009; Fernández et al., 2011a). Distribution of $\beta$-mannans and HRGPlike epitopes was shown to be found in two distinct cell wall layers, whereas sulfated polysaccharides were distributed in the middle area of the wall.

\section{CHAROPHYCEAE: CELL WALLS AND THE ORIGIN OF LAND PLANTS}

The Charophyceae or CGA are the extant group of green algae most closely related and ancestral to land plants. Over the past decade, a surge of research activity focusing on the walls of CGA taxa has revealed important insight into cell wall structure and evolution (Popper and Fry, 2003; Domozych et al., 2007, 2009; Eder et al., 2008; Eder and Lutz-Meindl, 2010; Popper and Tuohy, 2010; Sørensen et al., 2010, 2011; Popper et al., 2011). First, the cell walls of taxa of the early divergent CGA such as the Chlorokybales and Klebsormidiales, do not possess most of the polymers commonly found in late divergent CGA and land plants. The basal clade of CGA, the Mesostigmales, does not even have a cell wall but rather produces layers of scales (Domozych et al., 1991). Second, the late divergent clades, the Charales, Coleochaetales, and Zygnematales, possess cell walls with notable similarity to those of land plants. Polysaccharides like cellulose, pectins (including homogalacturonans and rhamnogalacturonan-I), $\beta$-(1-3) glucans, and hemicellulosic polymers like xyloglucans, mannans, and xylans are found in the cell wall of these advanced CGA. Mixed linkage glucans or MLGs that were once thought to be found only in members of the grass family of angiosperms, were also found in Zygnematalean taxa, demonstrating a more widespread occurrence in green plants. Also surprising is the presence of lignin-like compounds in the cell walls of several species of the genus Coleochaete.

Arabinogalactan proteins and extensin have also been described in many CGA taxa. Extensins surprisingly are not detected in Nitella and Chara (Charales; Gotteli and Cleland, 1968). Arabinosyltransferases involved in extensin arabinosylation belong to the GT77 A- and C-clades sensu Petersen et al. (2011) and it is remarkable that the Chara transcriptome (courtesy of Gernot Glöckner, Leibniz-Institute of Freshwater Ecology and Inland Fisheries, Berlin) as well as that of Nitella hyalina (Timme et al., 2012) each have a putative member in family GT77 clade D, but none in clade A or C. The transcriptome of Nitella, but not that of Chara comprises putative prolyl hydroxylases allowing for the existence of AGPs even though extensins are missing. It thus appears that members of Charales have evolved and separated themselves significantly from other members of the CGA, notably the Zygnematales and Coleochaetales which feature cell walls that more closely resemble that of vascular plants and which are known to express enzymes involved in cell wall metabolism akin to that observed in angiosperms (e.g., Vannerum et al., 2011). These latter similarities suggest that late divergent taxa of the CGA (i.e., their ancestors 470 million years ago) may have possessed cell wall characteristics that pre-adapted them for successful emergence onto and life on land.

\section{THE NEXT GOALS?}

More detailed characterization of the various taxa will be required before we can fully understand the evolution of extracellular coverings of green plants as well as adaptations to ECM chemistry in response to life in marine, freshwater, and terrestrial habitats. Some specific questions and areas of focus for future study include:

(1) Insights into the polysaccharide biosynthetic machinery of CGA are and will at the same time offer insights into the evolutionary events that accompanied adaptation to life on land. This will require full genomic sequencing as transcriptomic analysis is useful for demonstrating the functional expression of genes, but not for the absence. This endeavor offers many challenges as many relevant CGA genomes are estimated to be as big as if not bigger than that of Arabidopsis (Kapraun, 2007).

(2) Detailed analysis of the roles of cell wall polymers in the CGA is critical. Although the CGA share many cell wall constituents with their embryophyte descendents, it is not clear if they are used in equivalent roles.

(3) Sulfated polysaccharides from ulvophyte seaweeds have only recently been reexamined and have yet to be widely used in the hydrocolloid industry. Ulvan has been investigated as 
potential dietary fiber for human diet (Lahaye and Robic, 2007) due to its medical properties and potentially profitable extraction yields from harvested specimens. In addition, ulvans have some interesting biological activities, including acting as antioxidants, modifying certain macrophage activities, and serving as potential anti-hyperlipidemic agent (Wijesekara et al., 2011). Sulfated polysaccharides from the Bryopsidales are not obtained in large yields (Ciancia et al., 2007, 2012), but have piqued interest as bioactive compounds with several potential pharmacological applications (Ohta et al., 2009; Ciancia et al., 2010; Costa et al., 2010; Lee et al., 2010). More detailed characterization of these molecules is needed in order to fully recognize their potential.

(4) Comprehensive chemical and functional screening of the large but virtually unknown polysaccharide complexes secreted outside the cell walls of many Zygnematalean taxa (Domozych et al., 2005) will be important for understanding their physiology and importance to ecosystem dynamics.

\section{REFERENCES}

Adair, W. S., Steinmetz, S. A., Mattson, D. M., Goodenough, U. W., and Heuser, J. E. (1987). Nucleated assembly of Chlamydomonas and Volvox cell walls. J. Cell Biol. 105, 2373-2382.

Aquino, R. S., Grativol, C., and Mourão, P. A. S. (2011). Rising from the sea: correlations between sulfated polysaccharides and salinity in plants. PLoS ONE 6, el8862. doi:10.1371/journal.pone.0018862.

Becker, B., Becker, D., Kamerling, J. P., and Melkonian, M. (1991). 2-Ketosugar acids in green flagellates: a chemical marker for prasinophycean scales. J. Phycol. 27, 498-504.

Becker, B., and Marin, B. (2009). Streptophyte algae and the origin of embryophytes. Ann. Bot. 103, 999-1004

Becker, B., Marin, B., and Melkonian, M. (1994). Structure, composition, and biogenesis of prasinophyte cell coverings. Protoplasma 181, 233-244.

Bilan, M. I., Vinogradova, E. V., Shashkov, A. S., and Usov, A. I. (2007). Structure of a highly pyruvylated galactan sulfate from the pacific green alga Codium yezoense (Bryopsidales, Chlorophyta). Carbohydr. Res. 342, 586-596.

Blanc, G., Duncan, G., Agarkova, I., Borodovsky, M., Gurnon, J., Kuo, A., Lindquist, E., Lucas, S., Pangilinan, J., Polle, J., Salamov, A., Terry, A., Yamada, T., Dunigan, D. D., Grigoriev, I. V., Claverie, J. M., and Van Etten, J. L. (2010). The Chlorella variabilis NC64A genome reveals adaptation to photosymbiosis, coevolution with viruses, and cryptic sex. Plant Cell 22, 2943-2955.
Carpita, N. C., Defernez, M., Findlay, K., Wells, B., Shoue, D. A., CatchM. C. (2001). Cell wall architecture of the elongating maize coleoptile. Plant Physiol. 127, 551-565.

Cassolato, J. E. F., Noseda, M. D., Pujol, C. A., Pellizzari, F. M., Damonte, E. B., and Duarte, M. A. R. (2008). Chemical structure and antiviral activity of the sulfated heterorhamnan isolated from the green seaweed Gayralia oxysperma. Carbohydr. Res. 343, 3085-3095.

Chattopadhyay, K., Mandal, P., Lerouge, P., Driouich, A., Ghosal, P., and Ray, B. (2007a). Sulphated polysaccharides from Indian samples of Enteromorpha compressa (Ulvales, Chlorophyta): isolation and structural features. Food Chem. 104, 928-935.

Chattopadhyay, K., Adhikari, U., Lerouge, P., and Ray, B. (2007b). Polysaccharides from Caulerpa racemosa: purification and structural features. Carbohydr. Polym. 68, 407-415.

Ciancia, M., Alberghina, J., Arata, P. X., Benavides, H., Leliaert, F., Verbruggen, H., and Estevez, J. M. (2012). Characterization of cell wall polysaccharides of the coenocytic green seaweed Bryopsis plumosa (Bryopsidaceae, Chlorophyta) from the Argentine coast. J. Phycol. 48, 326-335.

Ciancia, M., Quintana, I., and Cerezo, A. S. (2010). Overview of anticoagulant activity of sulfated polysaccharides from seaweeds in relation to their structures, focusing on those of green seaweeds. Cur. Med. Chem. 17, 2503-2529.

Ciancia, M., Quintana, I., Vizcargüénaga, M. I., Kasulin, L., de Dios, pole, G., Wilson, R. H., and McCann,

The study of green algal cell walls and other coverings has now entered a truly exciting phase whereby new methodologies especially from the biochemical and molecular fronts are allowing for detailed resolution of wall polymers. While evolutionary and cell biology-based studies have been and will continue to be driving forces for this, the study of green algal coverings represents a critical step for emerging applied technologies as green algae are being, or will be, used as food sources for humans and domesticated animals, hydrocolloids for the food and pharmaceutical industry, bioactive compounds for medicinal use and starting material for biofuels.

\section{ACKNOWLEDGMENTS}

This work was supported by grants from CONICET (PIP 559/2010) and ANPCYT (PICT 2008-0500) of Argentina to Marina Ciancia, the Danish Research Council (FTP-09-066624) to Peter Ulvskov, the National Science Foundation (USA) grant MCB-0919925 to David S. Domozych.

A., Estevez, J. M., and Cerezo, A. S. (2007). Polysaccharides from the green seaweeds Codium fragile and C. vermilara with controversial effects on hemostasis. Int. J. Biol. Macromol. 41, 641-649.

Cordeiro, L. M., Carbonero, E. R., Sassaki, G. L., Reis, R. A., Stocker-Worgotter, E., Gorin, P. A. J., and Iacomini, M. (2006). A fungus-like $\beta$-galactofuranan in the cultivated Trebouxia photobiont of the lichen Ramalina gracilis. FEMS Microbiol. Lett. 244 193-198.

Costa, L. S., Fidelis, G. P., Cordeiro, S. L., Oliveira, R. M., Sabry, D. A., Cámara, R. B. G., Nobre, L. T. D. B,. Costa, M. S. S. P., Almeida-Lima, J., Farias, E. H. C., Leite, E. L., and Rocha, H. A. O. (2010). Biological activities of sulfated polysaccharides from tropical seaweeds. Biomed. Pharmacother. 64, 21-28.

Delwiche, C. F., and Timme, R. E. (2011). Plants. Cur. Biol. 21, R417R423.

Domozych, D. S., Brechka, H., Britton, A., and Toso, M. (2011). Cell wall growth and modulation dynamics in a model unicellular green alga Penium margaritaceum: live cell labeling with monoclonal antibodies. J. Bot. doi:10.1155/2011/632165

Domozych, D. S., Kort, S., Benton, S., and Yu, T. (2005). The extracellular polymeric substance of the green alga Penium margaritaceum and its role in biofilm formation. Biofilms 2, 1-16.

Domozych, D. S., Lambiasse, L., Kiemle, S. N., and Gretz, M. R. (2009). Cell-wall development and bipolar growth in the desmid Penium margaritaceum (Zygnematophyceae,
Streptophyta). Asymmetry in a symmetric world. J. Phycol. 45, 879-893.

Domozych, D. S., Serfis, A., Kiemle, S. N., and Gretz, M. R. (2007). The structure and biochemistry of charophycean cell walls. I. Pectins of Penium margaritaceum. Protoplasma 230, 99-115.

Domozych, D. S., Wells, B., and Shaw, P. J. (1991). The basket scales of the green alga Mesostigma viride: chemistry, immunology and ultrastructure. J. Cell Sci. 100, 397-407.

Dunn, E. K., Shoue, D. A., Huang, X., Kline, R. E. L., MacKay, A. L., Carpita, N. C., Taylor, I. E. P., and Mandoli, D. F. (2007). Spectroscopic and biochemical analysis of regions of the cell wall of the unicellular 'mannan weed', Acetabularia acetabulum. Plant Cell Physiol. 48, 122-133.

Eder, M., and Lutz-Meindl, U. (2010). Analyses and localization of pectinlike carbohydrates in cell wall and mucilage of the green alga Netrium digitus. Protoplasma 243, 25-38.

Eder, M., Tenhaken, R., Driouich, A., and Lutz-Meindl, U. (2008). Occurrence and characterization of arabinogalactan-like proteins and hemicelluloses in Micrasterias (Streptophyta). J. Phycol. 44, 1221-1234.

Egelund, J., Obel, N., Ulvskov, P., Geshi, N., Pauly, M., Bacic, A., and Petersen, B. L. (2007). Molecular characterization of two Arabidopsis thaliana glycosyltransferase mutants, rral and rra2, which have a reduced residual arabinose content in a polymer tightly associated with the cellulosic wall residue. Plant Mol. Biol. 64, 439-451. 
Estevez, J. M., Leonardi, P. I., and Alberghina, J. S. (2008). Cell wall carbohydrate epitopes in the green alga Oedogonium bharuchae F. minor (Oedogoniales, Chlorophyta). J. Phycol. 44, 1257-1268.

Estevez, J. M, Kasuli, L., Fernandez, P. V., Dupree, P., and Ciancia, M. (2009). Chemical in situ characterization of macromolecular components of the complex cell walls from the coenocytic green alga Codium fragile. Glycobiology 18, 250-259.

Farias, E. H. C., Pomin, V. H., Valente, A. P., Nader, H. B., Rocha, H. A. O., and Mourão, P. A. S. (2008). A preponderantly 4-sulfated, 3linked galactan from the green alga Codium isthmocladum. Glycobiology 18, 250-259.

Fernández, P. V., Ciancia, M., and Estevez, J. M. (2011a). Cell wall variability in the green seaweed Codium vermilara (Bryopsidales Chlorophyta) from the Argentine coast. $J$. Phycol. 47, 802-810.

Fernández, P. V., Ciancia, M., Miravalles, A. B., and Estevez, J. M. (2011b). Cell-wall polymer mapping in the coenocytic macroalga Codium vermilaria (Bryopsidales, Chlorophyta). J. Phycol. 46, 456-465.

Finet, C., Timme, R. E., Delwiche, C. F., and Marlétaz, F. (2010). Multigene phylogeny of the green lineage reveals the origin and diversification of land plants. Cur. Biol. 20, 2217-2222.

Gotteli, L. B., and Cleland, R. (1968). Differences in the occurrence and distribution of hydroxyprolineproteins among the algae. Am. J. Bot. 55, 907-914.

Huizing, H. J., and Rietema, H. (1975). Xylan and mannan as cell wall constituents of different stages in the life-histories of some siphoneous green algae. Br. Phycol. J. 10, 13-16.

Huizing, H. J., Rietema, H., and Sietsma, J. H. (1979). Cell wall constituents of several siphoneous green algae in relation to morphology and taxonomy. Br. Phycol. J. 14, 25-32.

Imam S. H., Buchanan, M. J., Shin, H.-C., and Snell, W. J. (1985). The Chlamydomonas cell wall: characterization of the wall framework. J. Cell Biol. 101, 1599-1607.

Kapraun, D. F. (2007). Nuclear DNA content estimates in green algal lineages: Chlorophyta and Streptophyta. Ann. Bot. 99, 677-701.

Keskiaho, K., Hieta, R., Sormunen, R., and Myllyharju, J. (2007). Chlamydomonas reinhardtii has multiple prolyl 4-hydroxylases, one of which is essential for proper cell wall assembly. Plant Cell 19, 256-269.
Kieliszewski, M. J., and Lamport, D. T. A. (1994). Extensin: repetitive motifs, functional sites, posttranslational codes and phylogeny. Plant J. 5, 157-172.

Kirk, D. L. (1998). Volvox. New York: Cambridge University Press.

Lahaye, M., and Robic, A. (2007) Structure and functional properties of ulvan, a polysaccharide from green seaweeds. Biomacromolecules 8, 1766-1774.

Lee, J.-B., Ohta, Y., Hayashi, K., and Hayashi, T. (2010). Immunostimulating effects of a sulfated galactan from Codium fragile. Carbohydr. Res. 345, 1452-1454

Leliaert, F., Smith, D. R., Moreau, H., Herron, M., Verbruggen, H., Delwiche, C. F., and De Clerck, O. (2012). Phylogeny and molecular evolution of the green algae. Crit. Rev. Plant Sci. 31, 1-46.

Leliaert, F., Verbruggen, H., and Zechman, F. W. (2011). Into the deep: new discoveries at the base of the green plant phylogeny. Bioessays 33, 683-692.

Lewis, L. A., and McCourt, R. M. (2004). Green algae and the origin of land plants. Am. J. Bot. 91, 1535-1556.

Mao, W., Li, H., Li, Y., Zhang, H., Qi, X., Sun, H., Chen, Y., and Guo, S. (2009). Chemical characteristic and anticoagulant activity of the sulfated polysaccharide isolated from Monostroma latissimum (Chlorophyta). Int. J. Biol. Macromol. 44, 70-74.

Mao, W.-J., Fang, F., Li, H.-Y., Qi, X.-H., Sun, H.-H., Chen, Y., and Guo, S.-D. (2008). Heparinoidactive two sulfated polysaccharides isolated from marine green algae Monostroma nitidum. Carbohydr. Polym. 74, 834-839.

Moestrup, O., and Walne, P. L. (1979). Studies on scale morphogenesis in the Golgi apparatus of Pyramimonas tetrarhynchus (Prasinophyceae). J. Cell Sci. 36, 437-459.

Moller, I., Sørensen, I., Bernal, A. J., Blaukopf, C., Lee, K., Øbro, J., Pettolino, F., Roberts, A., Mikkelsen, J., Knox, J. P., Bacic, T., and Willats W. G. T. (2007). High-throughput mapping of cell wall polymers within and between plants using novel microarrays. Plant J. 50, 1118-1128.

Ohta, Y., Lee, J.-B., Hayashi, K., and Hayashi, T. (2009). Isolation of sulfated galactan from Codium fragile and its antiviral effect. Biol. Pharm. Bull. 32, 892-898.

Painter, T. J. (1983). "Algal polysaccharides," in The Polysaccharides, Vol. 2, ed. G. O. Aspinall (New York, NY: Academic Press), 827-837.
Percival, E. (1979). The polysaccharides of green, red, and brown seaweeds: their basic structure, biosynthesis and function. Br. Phycol. J. 14, 103-117.

Percival, E., and McDowell, R. H. (1981). "Algal walls. Composition and biosynthesis," in Encyclopedia of Plant Physiology, Vol. 13B, eds W. Tanner and F. A. Loewus (Berlin: Springer), 277-316.

Petersen, B. L., Faber, K., and Ulvskov, P. (2011). "Glycosyltransferases of the GT77 family," in Annual Plant Reviews: Plant Polysaccharides, Biosynthesis, and Bioengineering, ed. P. Ulvskov (New York: Blackwell), 305-320.

Piganeau, G., Grimsley, N., and Moreau, H. (2011). Genome diversity in the smallest marine photosynthetic eukaryotes. Res. Microbiol. 62, 570577

Popper, Z. A., and Fry, S. C. (2003). Primary cell wall composition of bryophytes and charophytes. Ann. Bot. 91, 1-12.

Popper, Z. A., Michel, G., Herve, C., Domozych, D. S., Willats, W. G. T., Tuohy, M. G., Kloareg, B., and Stengel, D. B. (2011). Evolution and diversity of plant cell walls: from algae to flowering plants. Annu. Rev. Plant Biol. 62, 567-590.

Popper, Z. A., and Tuohy, M. G. (2010). Beyond the green: understanding the evolutionary puzzle of plant and algal cell walls. Plant Physiol. 153, 373-383.

Rautengarten, C., Ebert, B., Herter, T., Petzoldc, C. J., Ishii, T., Mukhopadhyay, A., Usadel, B., and Schellera, H. V. (2011). The interconversion of UDP-Arabinopyranose and UDPArabinofuranose is indispensable for plant development in Arabidopsis. Plant Cell 23, 1373-1390.

Ray, B. (2006). Polysaccharides from Enteromorpha compressa: isolation, purification and structural features. Carbohydr. Polym. 66, 408-416.

Rodrigues, M. A., and da Silva Bon, E. P. (2011). Evaluation of Chlorella (Chlorophyta) as source of fermentable sugars via cell wall enzymatic hydrolysis. Enzyme Res. doi:4061/2011/405603

Showalter, A. M., Keppler, B., Lichtenberg, J., Gu, D., and Welch, L. R. (2010). A bioinformatics approach to the identification, classification, and analysis of hydroxyproline-rich glycoproteins. Plant Physiol. 153, 485-513.

Sørensen, I., Domozych, D., and Willats, W. G. T. (2010). How have plant cells walls evolved? Plant Physiol. 153, 366-372.
Sørensen, I., Pettolino, F. A., Bacic, A., Ralph, J., Lu, F., O’Neill, M. A., Fei, Z. Rose, J. K. C., Domozych, D. S., and Willats, W. G. T. (2011). The Charophycean green algae provide insights into early origin of plant cell walls. Plant J. 153, 366-372.

Sørensen, I., Rose, J. K. C., Doyle, J. J., Domozych, D. S., and Willats, W. G. T. (2012). The Charophycean green algae as model systems to study plant cell walls and other evolutionary adaptations that gave rise to land plant. Plant Signal. Behav. 7, 1-3.

Timme, R. E., Bachvaroff, T. R., and Delwiche, C. F. (2012). Broad phylogenomic sampling and the sister lineage of land plants. PLoS ONE 7, e29696. doi: 10.1371/journal.pone.0029696

Timme, R. E., and Delwiche, C. F. (2010). Uncovering the evolutionary origin of plant molecular processes: comparison of Coleochaete (Coleochaetales) and Spirogyra (Zygnematales) transcriptomes. BMC Plant Biol. 10, 96. doi:10.1186/1471-2229-10-96

Vannerum, K., Huysman, M. J. J., De Rycke, R., Vuylsteke, M., Leilaert, F., Pollier, J., Lutz-Meindl, U., Gillard, J., DeVeylder, L., Goossens, A., Inze, D., and Vyverman, W. (2011). Transcriptional analysis of cell growth and morphogenesis in the unicellular green alga Micrasterias (Streptophyta), with emphasis on the role of expansin. BMC Plant Biol. 11, 128. doi:10.1186/1471-2229-11-128

Velasquez, S. M., Ricardi, M. M., Dorosz, J. G., Fernandez, P. V., Nadra, A. D., Pol-Fachin, L., Egelund, J., Gille, S., Harholt, J., Ciancia, M., Verli, H., Pauly, M., Bacic, A., Olsen, C. E., Ulvskov, P., Petersen, B. L., Somerville, C., Iusem, N. D., and Estevez, J. M. (2011). O-glycosylated cell wall proteins are essential in root hair growth. Science 332, 1401-1403.

Voigt, J., Liebich, I., Kieß, M., and Frank, R. (2001). Subcellular distribution of 14-3-3 proteins in the unicellular green alga Chlamydomonas reinhardtii. Eur. J. Biochem. 268, 6449-6457.

Voigt, J., Woestemeyer, J., and Frank, R. (2007). The chaotrope-soluble glycoprotein GP2 is a precursor of the insoluble glycoprotein framework of the Chlamydomonas cell wall. J. Biol. Chem. 282, 30381-30392.

Wijesekara, I., Pangestuti, R., and Kim, S.-K. (2011). Biological activities and potential health benefits of sulfated polysaccharides derived from marine algae. Carbohydr. Polym. 84, 14-21. 
Wodnick, S., Brinkmann, H., Glockner, G., Heidel, A. J., Philippe, H., Melkonian, M., and Becker, B. (2011). Origin of land plants: do conjugating green algae hold the key? BMC Evol. Biol. 11, 104. doi:10.1186/1471-2148-11-104

Wutz, M., and Zetsche, K. (1976). Zur Biochimie und Regulation des Heteromorphen Generationswechsels der Grünalge. Planta 129, 211-216.
Yamagaki, T., Maeda, M., Kanazawa, K., Ishizuka, Y., and Nakanishi, H. (1997). Structural clarification of Caulerpa cell wall $\beta$ - $(1 \rightarrow 3)$-xylan by NMR spectroscopy. Biosci. Biotechnol. Biochem. 61, 1077-1080.

Conflict of Interest Statement: The authors declare that the research was conducted in the absence of any commercial or financial relationships that could be construed as a potential conflict of interest.

Received: 10 March 2012; accepted: 12 April 2012; published online: 08 May 2012.

Citation: Domozych DS, Ciancia M, Fangel JU, Mikkelsen MD, Ulvskov $P$ and Willats WGT (2012) The cell walls of green algae: a journey through evolution and diversity. Front. Plant Sci. 3:82. doi: 10.3389/fpls.2012.00082
This article was submitted to Frontiers in Plant Physiology, a specialty of Frontiers in Plant Science.

Copyright (C) 2012 Domozych, Ciancia Fangel, Mikkelsen, Ulvskov and Willats. This is an open-access article distributed under the terms of the Creative Commons Attribution Non Commercial License, which permits non-commercial use, distribution, and reproduction in other forums, provided the original authors and source are credited. 